УДК.621.791.92.042

Кассов В. Д., Кабацький О. В., Бережна О. В., Малигіна С. В.

\title{
ГАЗОПОВІТРЯНИЙ НАГРІВАЧ ДЛЯ НАГРІВУ ДЕТАЛЕЙ ОБЕРТАННЯ ПРИ ЗВАРЮВАННІ ТА НАПЛАВЛЕННІ
}

Одним з важливих етапів технології наплавлення масивних великогабаритних деталей $\epsilon$ нагрів їх до необхідної температури. Нагрівання може здійснюватися попередньо, а також в процесі зварювання або наплавлення деталей. При цьому, як показує практика, неможливість підтримувати прийняті параметри нагріву неминуче призводить до утворення дефектів в наплавленому шарі (тріщини, відшарування і ін.) [1-3]. Вирішенню даного питання надається суттєве значення.

В процесі наплавлення робочих поверхонь деталей обертання в якості нагріваючих пристроїв часто використовують потужні газові пальники або електричні індуктори [1]. При цьому деталь, що має обертальний рух, нагрівається відкритим полум'ям, що створює певні незручності. Так, наприклад, при тривалому циклі наплавлення від розплавлених газів (продуктів згоряння) може перегріватися зварювальна головка, що призведе до іiі передчасного виходу з ладу. Крім цього, вести якісне наплавлення при такому способі нагріву важко для наплавників. Це зумовлено тим, що майже неможливо наблизитися до деталі, тому що заважає потік розпечених газів, що омивають деталь, яку наплавляють.

Нагрівання деталей електричними індукторами має ряд недоліків. Індуктори живляться від джерела електричного струму напругою $380 \mathrm{~B}$, яке небезпечно для життя зварників. Вести наплавлення з встановленим на деталь індуктором досить важко. При наближенні зварювальної головки індуктор необхідно переміщати, при цьому його потрібно знеструмлювати.

При нагріванні індуктором важко підтримувати температуру в інтервалі $400-500{ }^{\circ} \mathrm{C}$ через велику втрату тепла поверхнею деталі.

Виходячи із сказаного, за мету роботи було поставлене вдосконалення устаткування для стабільного й безпечного підтримання процесу нагріву деталей при зварюванні та наплавленні.

Значно знизити втрати тепла і виконувати наплавлення без перерв може дозволить використання газоповітряного нагрівача.

Нагрівання наплавлюваної деталі газоповітряним полум'ям здійснюється за наступною схемою (рис. 1). Полум'ям пальників нагрівається внутрішній лист утеплювача, випромінюваним теплом від якого нагрівається деталь. Розпечені гази, продукти згоряння відводяться в безпечне місце.

Розрахунок пальників нагрівача проводиться за їх тепловою потужністю, із застосуванням відомих емпіричних формул. Так, повна теплова потужність $Q n$ для нагрівання виробу циліндричної форми знаходиться за формулою [4]:

$$
Q_{\Pi}=\left[\left(\frac{T_{\mathrm{K}}}{100}\right)^{4}-\left(\frac{T_{\mathrm{B}}}{100}\right)^{4}\right] \cdot F_{\mathrm{B}},
$$

де $T \kappa$ - мінімальна температура нагріваючої стінки кожуху, з практики нагріву заготівок приймаємо Тк $=1000^{\circ} \mathrm{C}$;

$T 6$ - мінімальна температура нагріву виробу, $T 6=500-550^{\circ} \mathrm{C}$

$F b$ - площа поверхні виробу, що нагрівається, для розрахунку приймаємо поверхню циліндричної форми діаметру 1,5-2,0 м. Наприклад, для опорного валку стану холодного прокату «1700»Fв $=2,59 \mathrm{~m}^{2}$. 


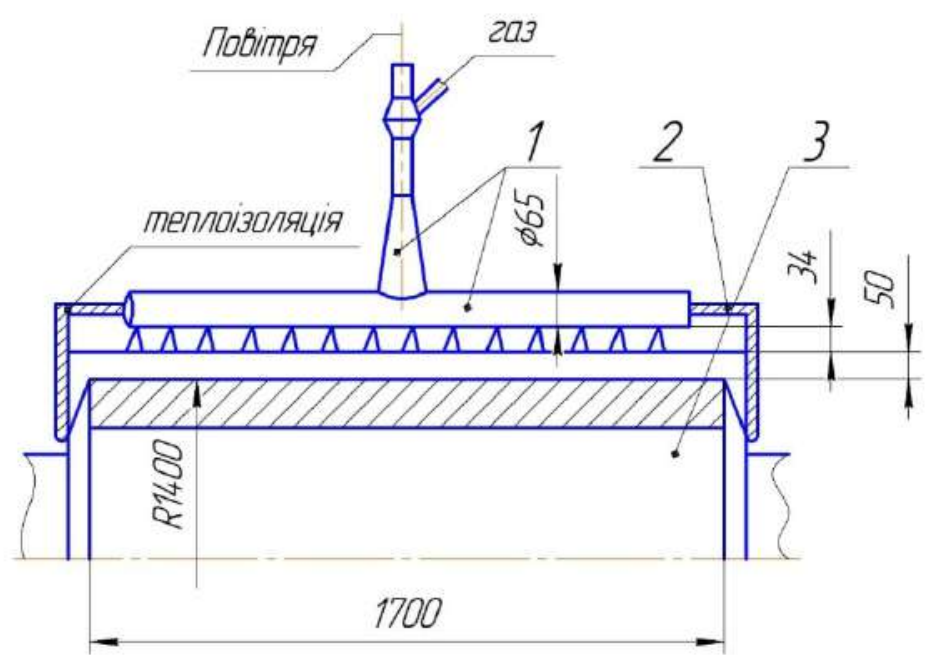

Рис. 1. Схема підігріву деталі при наплавленні:

1 - газова горілка; 2 - кожух 3 жаростійкої сталі; 3 - деталь, що нагрівають

Згідно розрахунку $Q_{n}=58358$ ккал/год.

Далі за числовим значенням необхідної теплової потужності джерела підбираємо тип пальників та їх кількість.

Вибір пальників здійснюється за нормалями машинобудування. Враховуючи специфіку роботи пальників (у закритому просторі), вибираємо пальники із тепловою потужністю 55000 ккал/год. (рис. 2). Враховуючи неминучі втрати тепла при наплавленні а також за конструктивними міркуваннями встановлюємо у нагрівач три пальники.

Було також здійснено перевірочний розрахунок пальнику. Виконано розрахунок на відсутність проскакування полум'я. Воно виникає, коли хоч би в одній точці фронту полум'я швидкість поширення полум'я перевищує швидкість витікання газоповітряної суміші. Виникнення проскакування полум'я залежить від характеристики горючого газу, складу, температури і витрати газоповітряної суміші, діаметру вогневого отвору і характеру розподілу швидкостей у вихідному отворі $[4,5]$. Деякий вплив може робити також і форма вогневого каналу.

Розрахунок виконано за рекомендаціями [6]. У його основі є перевищення фактичного значення параметра відношення розходу газу до діаметру отвору (кратеру), взятому у кубі $\left(V / d^{3}{ }_{\kappa p}\right)$ за його допустиме значення для газоповітряної суміші, що використовується у пальнику. Знайдено, що при даних умовах таке перевищення задовольняється, отже проскакування полум'я не спостерігатиметься.

Було виконано також розрахунок розміру вихідного сопла пальнику. Виходячи з рекомендацій [7], знайдено діаметр сопла таким, що складає 2,3 мм.

Нагрівач (рис. 3) складається 3 двох рознімних половин (передньої і задньої), що представляють собою порожнини, усередині яких встановлено три пальники. У задній половині нагрівача розташовано два пальники, в передній - один. Обидві половини вільно поступально переміщаються в напрямку поздовжньої осьової лінії установки, що зручно при установці деталі під наплавлення, а також при їі знятті. Зверху і знизу половини нагрівача замикаються, утворюючи при цьому зазори для зручності наплавлення і переміщення зварювальної головки вгорі, і прибирання флюсової кірки і флюсу внизу.

Оскільки пальники розташовані в закритому просторі нагрівача, потрапляння гарячих газів (продуктів згоряння) на зварювальну головку виключається, і поліпшуються умови роботи наплавників. 


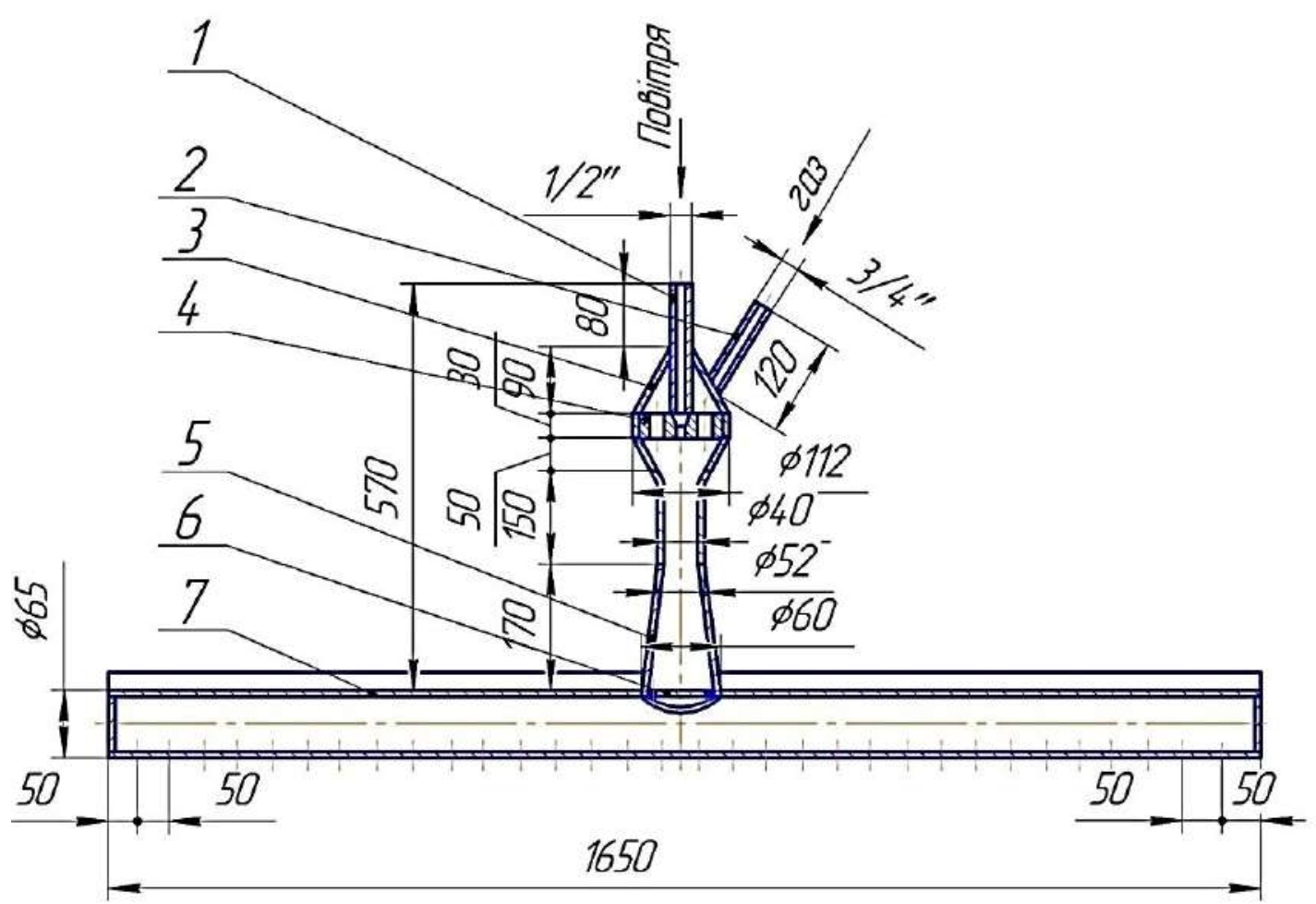

Рис. 2. Конструкція безполум'яного інжекторного пальнику:

1 - штуцер підводу газу; 2 - штуцер повітряний; 3 - корпус інжектору; 4 - сопло; 5 - змішувач; 6 - розподілювач; 7 - корпус пальнику; 8 - ребро жорсткості

Відведення продуктів згоряння 3 нагрівача здійснюється по 4-м патрубкам, які відведені вгору і в бік, не заважаючи пересуванню зварювальної головки.

Для зручності ведення процесу наплавлення i, особливо, видалення шлакової кірки верх на передній половині нагрівача окружності-периметра нагрівача накривається легкими знімними сталевими фартухами (5 шт.). Зовнішня оболонка нагрівача, а також фартухи теплоізольовані від навколишнього середовища асбестотканиною в поєднанні зі сталевою сіткою.

Нагрівач працює при високих температурах, а тому виготовляється з нержавіючої жаростійкої листової сталі товщиною 4 мм. У радіальному напрямку для жорсткості корпусу приварені 5 ребер жорсткості, пальники також посилені ребрами жорсткості. Усі три пальники розташовані симетрично до поздовжньої осі нагрівача на відстані 50 мм від екрану, встановленого на внутрішній стінці нагрівача для зниження його підгоряння від полум'я пальника.

Живлення пальників газами здійснюється по гумових шлангах 3 внутрішнім діаметром 18 мм довжиною 6 м від цехової магістралі газу та повітря. За допомогою вентилів можна регулювати подачу повітря і газу.

Даний нагрівач було апробовано при здійсненні попереднього підігріву при наплавленні порошковим дротом складної конструкції [7] великогабаритної деталі типу валу із сталі, що містить 0,5 \% вуглецю, основу легування якої (до 11-12\%) становить хром. При цьому сталь додатково легували вольфрамом, молібденом і ванадієм. В якості металу, що наплавляється, використовували високохромисту сталь, близьку за складом до основного металу, модифіковану магнієво-алюмінієвою лігатурою. Встановлено, що використання пропонованого нагрівачу дозволило здійснювати більш рівномірне й ефективне нагрівання, що разом iз іншими чинниками дозволило отримати якісний наплавлений метал (рис. 4).

Таким чином, використання нагрівача може бути рекомендоване при зварюванні та наплавленні деталей обертання в умовах виробництва. 


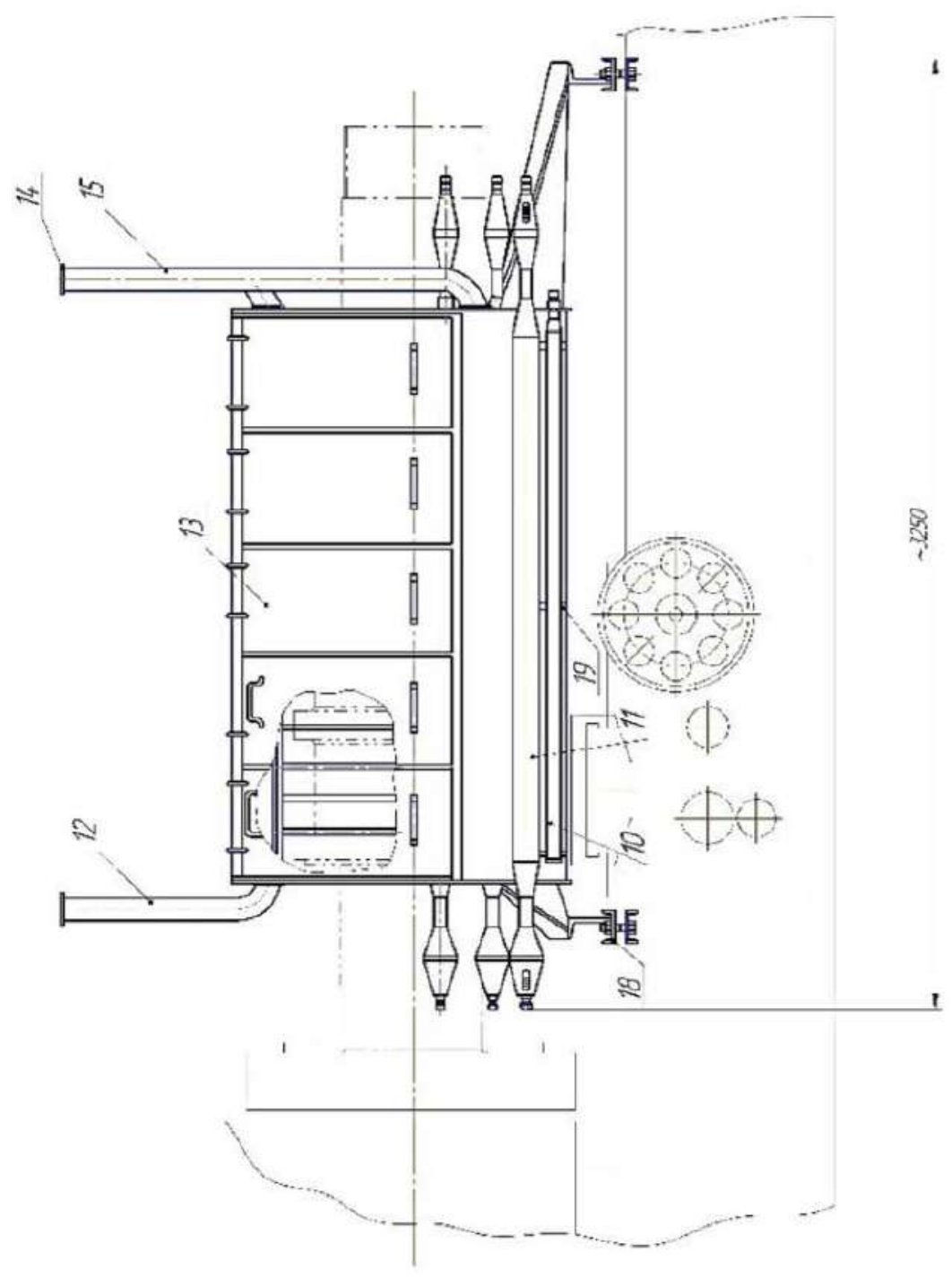

芒

旨常

$1 \pm x$

$\ddot{z} \ddot{\theta}$

응 盯

tr 1

元

o 0

涵

를

$\exists \times$ ।

$\stackrel{m \infty}{m}$

$\overline{2} \times \div$

홍ㅇํ

1

n

$\ddot{\theta}=$

$\ddot{\overline{\mathrm{E}}} \tilde{\mathrm{\sigma}}$

능

可哥

幽

氞菏

잉

总

角苟婇

은

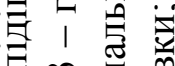

$\exists \cdots$ 疍

旨

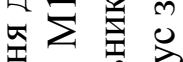

焉客悬

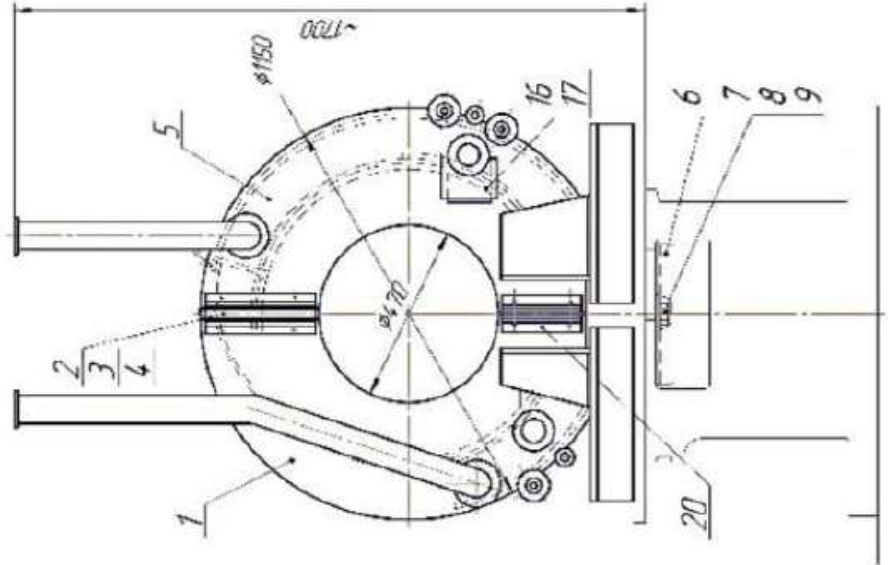

द 11

N의

己 $\ddot{\vec{\Delta}} \ddot{0}$

뜽

뾰 0

늘 웝 옹

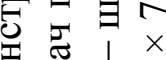

吾

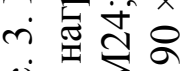

ن $1 \sum_{\pi}$

喼总 in 


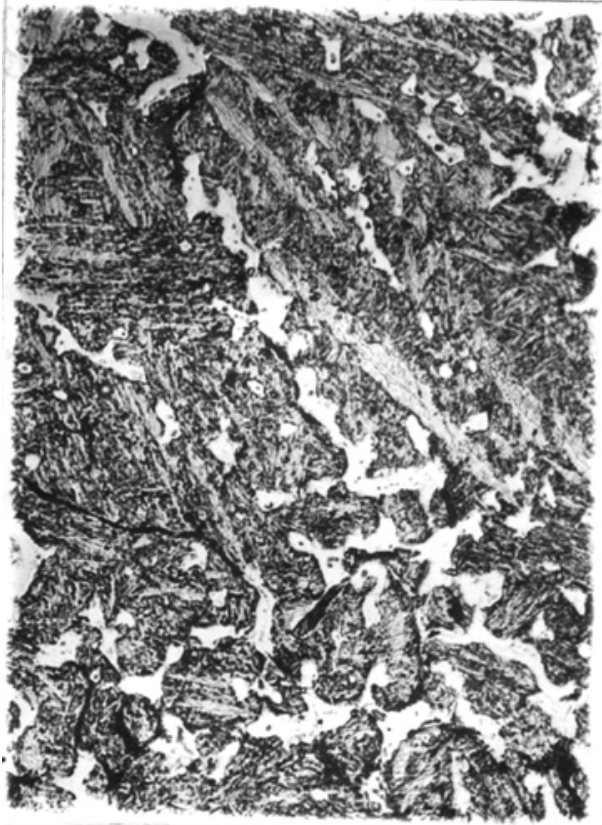

a

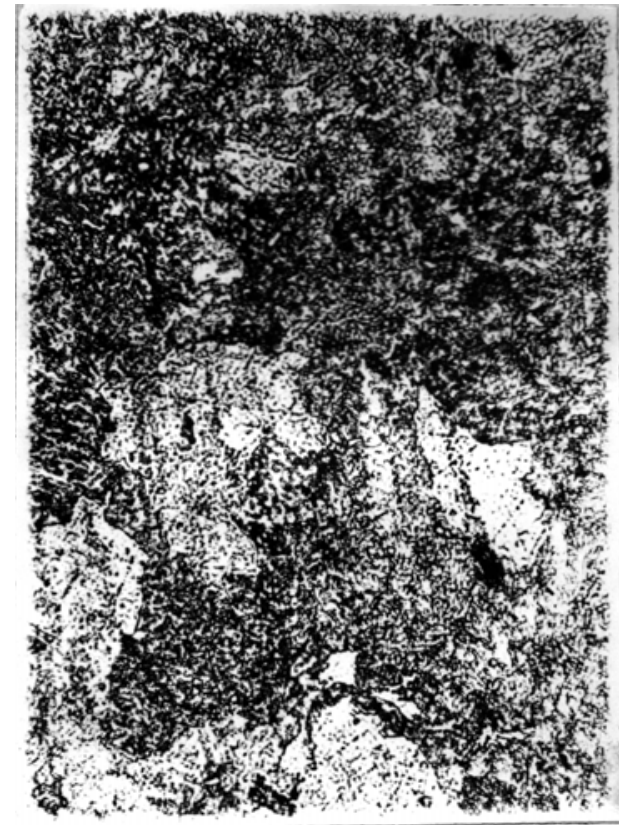

6

Рис. 4. Мікроструктура наплавленого металу останнього валику (а) та після високого відпущення (б), × 500

\section{ВИСНОВКИ}

Запропоновано конструкцію газоповітряного нагрівача для зварювання й наплавлення. При цьому газоповітряним полум'ям пальників нагрівається внутрішній лист утеплювача, випромінюваним теплом від якого нагрівається деталь. Розпечені гази, продукти згоряння відводяться в безпечне місце.

Як показали випробування, вибрана конструкція нагрівача дозволяє забезпечити стабільність й безпечність процесу нагріву деталей при зварюванні та наплавленні, значно знизити втрати тепла і виконувати наплавлення без перерв.

Використання нагрівача може бути рекомендоване при зварюванні та наплавленні деталей обертання в умовах виробництва.

\section{СПИСОК ВИКОРИСТАНОЇ ЛІТЕРАТУРИ}

1. Сомонов В. В. Влияние индукиионного нагрева на предотвращение образования горячих трещин при лазерной сварке алюминиевых сплавов / В. В. Сомонов // Научно-технические ведомости Санкт-Петербургского государственного политехнического университета. - 2013 - № 1. - C. 237-243.

2. Полетаев Ю. В. Влияние термического иикла сварки и повторного нагрева на структурно-фазовые изменения низколегированной Cr-Ni-Mo-V стали / Ю. В. Полетаев, В. Ю. Полетаев // Вестник Донского государственного технического университета. - 2016. - № 4(87). - C. 96-103.

3. Повышение работоспособности наплавленных крановых колес / В.П. Иванов, Ю. В Сергиенко, Е.Н. Сорочан, Е. В. Таранина // Наука та виробництво: міжвузівський тематичний збірник наукових праць. Маріуполь : ДВНЗ «ПДТУ», 2017. - Вun. 17-C. 49-53.

4. Богомолов А. И. Газовые горелки инфракрасного излучения и их применение / А. И. Богомолов, Д. Я. Вигдорчик, М. А. Маевский. - М. : Издательство литературы по строительству, 1967. - 256 с.

5. Пелипенко В. Н. Газовые горелки инфракрасного излучения / В. Н. Пелипенко, Д. Ю. Слесарев. - Тольятти : Изд-во ТГУ, 2012. - $118 \mathrm{c}$.

6. Крыжановский Ю. В. Структура и расчет газового факела / Ю.В.Крыжановский, В. Н. Крыжановский. - К. : Освіта Украӥни, 2012. - 96 с.

7. Технологические особенности изготовления и наплавки с использованием порошковой проволоки сложной конструкции / В. Д. Кассов, А. В. Кабаџкий, Е. В. Бережная, С. В. Мальгина // Вісник ДДМА : зб. наук. праиьь. - Краматорськ : ДДМА, 2018. - № 2(44). - С. 47-51. 